\title{
Narrative Strategies Giving Voice to the Silenced Subject
}

\section{The Horse in Fiction for Children}

\begin{abstract}
This article uses an ecocritical, posthumanist animal studies approach to fiction about horses for children and young adults in order to show how different narrative strategies co-exist within a framework of silence versus voice and Othering versus anthropomorphizing. The examples are taken from two Swedish series of books: the stories of Vitnos (1971-1980) by Marie Louise Rudolfsson, and those about Klara (1999-2008) by Pia Hagmar. The study shows that regardless of the narrative form chosen, be it placing the horse as a first-person narrator or introducing a human narrator and focalizer, the result is quite similar. The horse is alternately anthropomorphized and depicted as Other, many times through the technique of allomorphism, placing the horse above the human being.
\end{abstract}

Keywords: fiction about horses, ecocriticism, posthumanism, animal studies, anthropomorphism, allomorphism, Othering, silenced subject, voice, narration, Pia Hagmar, Marie Louise Rudolfsson

C2020 A-S Persson. This is an Open Access article distributed under the terms of the Creative Commons Attribution-Noncommercial 3.0 Unported License (http://creativecommons.org/ licenses/by-nc/3.0/), permitting all non-commercial use, distribution, and reproduction in any medium, provided the original work is properly cited.

Citation: Barnboken - tidskrift för barnlitteraturforskning/Journal of Children's Literature Research, Vol. 43, 2020 http:/ /dx.doi.org/10.14811/clr.v43.539 
Within the specific genre devoted to horses and the people involved in their care, the stories written for children and young adults take on a variety of aspects, depicting wild horses as well as tame, privately owned or belonging to a pony club (Hedenborg 176). Often evolving around the friendship or animosity that occur between the characters (Asklund 251-252), the stories also depict the communicative efforts between riders and horses, involved in interspecies interaction (Nyrnes 5-7). Most of the time, the narration of the story is taken care of by an omniscient human narrator or by the main character, who is simultaneously the main focalizer of the story. Sometimes, however, the horse is the narrator of the story, the most well-known example being that of Black Beauty, written in 1877 by Anna Sewell, with the clear purpose of commenting on the ill treatment of the horse, in order to change the situation (Hedenborg 176; Cosslett 5; Ratelle 11).

When a horse serves as the narrator of the story, and thus steps out of silence, he is attributed certain human traits, for instance the capacity of speech. Descriptions of the horse from a human narrator's perspective can imply that the animal resembles a human or is distinct from him, described as Other. These contrasting narrative strategies in use within the depiction of horses are the focus of this study. The aim of this article is to show how the processes of giving voice to the silenced horse, regardless of the narrative technique used, blend the opposing strategies of Othering on the one hand and assigning human traits, anthropomorphism, on the other. The method employed is close readings of selected examples of depictions of the horse where knowledge and understanding of the situation at hand, sometimes including human-horse interaction, are in particular focus. The analysis will concentrate on the horse narrator in Marie Louise Rudolfsson's Vitnos, det lilla russet (Vitnos, the Little Russ, 1971), Vitnos räddar Guldvinge (Vitnos Saves Guldvinge, 1975), and Vitnos och den bråkiga kattungen (Vitnos and the Mischievous Kitten, 1976), and will then turn to Pia Hagmar's Klaras ridlägersommar (Klara's Riding Camp Summer, 2000) to study the depictions of the horse from a human perspective.

There are nineteen books on Vitnos, written between 1971 and 1980. The story starts around the birth of Vitnos and covers a short period of time during which Vitnos remains a foal. Born on the island of Gotland, among the wild ponies, Vitnos tells us the story of his capture by humans to be the pony of a young girl, and the adventures that follow. The first volume of the series, Vitnos, det lilla russet, includes scenes where the foal Vitnos discovers things new to him and exposes his ignorance. This makes it suitable for the study of the foal narrator as a child, since they both represent silenced Others to the adult human world, following the thoughts of Christopher 
Manes (16) and Josephine Donovan (213). Although Vitnos speaks throughout the series and thus does not seem to be silenced, one must bear in mind that this, of course, is a construction by the author and thus an adult human mimicking the horse. Furthermore, the implied reader is a child and Vitnos creates a dialogue without addressing the adult directly, as if creating a special bond, a complicity between subordinate yet hierarchically positioned subjects. The remainder of the volumes are practically interchangeable when it comes to investigating Vitnos behaving as an expert, but volumes number ten and eleven - Vitnos räddar Guldvinge and Vitnos och den bråkiga kattungen - have been selected since they provide a number of passages that show particularly well Vitnos underlining his superiority, compared to humans.

The series on Klara (1999-2008) comprises eighteen books, about the same number of volumes as Vitnos, published about twenty years later and written for a slightly older audience (6-9 years old for Vitnos, 9-12 for Klara). It has a first-person narrator and focalizer, Klara, depicting the horse from a human perspective, operating a clear shift compared to the stories told by Vitnos. Klara reads the signs of the horse and speaks for him, making his voice indirectly heard to the reader. Filtered through the sensibility of Klara, interpreted thanks to her knowledge, the image of the horse thus projected adjusts to the human-oriented, anthropocentric perspective, while at the same time clearly representing the horse as Other, as that which is different from the human. Volume number six, Klaras ridlägersommar, was selected because it belongs to the earlier part of the series, where Klara is still on a steep learning curve in the handling of horses. In addition, this narrative deals with Klara going to a nearby equestrian center to learn more about riding. It is thus a volume where the humanhorse, rather than human-human, interaction is at the forefront. It is a more complex narrative than the ones on Vitnos and thus one single volume is sufficient as a point of comparison.

In the following, the discussion will initially focus on a few examples of the talkative Vitnos as an expression of the silenced child. Then, the analysis will show how this reading of the anthropomorphized horse limits the scope and clouds the construction of the horse as a non-human silenced Other. Lastly, examples of the silent horse taken from the Klara series will be considered and discussed, both in relation to the anthropomorphic view of the horse and in contrast to the process of Othering. The theories used to frame the analysis - ecocriticism, animal studies and posthumanism, as well as studies on animals in children's books - will receive a more thorough presentation below. 


\section{From Speaking Animals to a Nature-Centered Approach to Horses}

The books on Vitnos belong to a long tradition in children's literature going even further back than the autobiography of Black Beauty. Kathleen R. Johnson (relying on May Hill Arbuthnot and Zena Sutherland) distinguishes three different kinds of stories including animals - one where animals conduct themselves as humans, one where animals get to be themselves but can talk and yet another where the animals appear "as their real selves" (19). Speaking animals regularly inhabit stories for a younger audience, often with the didactic purpose of creating empathy for animals within the reader (Cosslett 63). Hiding behind the talkative animal is the author responsible for raising ethical questions with the help of animal narrators (Cosslett 64). Other times, the animal serves as a representation of the child (Nikolajeva 157), metaphorically disguised as an animal, while at the same time assigned human traits (155). These stories may depict the ridicule of human behavior compared to animals involved in a "[p]icaresque adventure" or be used to spread knowledge of nature (Cosslett 64). Animals also function as tools of empowering the child (Nikolajeva 155-156), and instances of rebellious behavior on the part of the animal represent the subversion of adult rule (162). The animal (and by extension the child) talks back, so to speak, to the normative world of adults, through unwanted behavior. Language is also an issue when animals talk in fiction for children. According to Tess Cosslett, humans rarely understand the non-human animals, except for the implied child reader, considered somehow closer to the natural world, just as other oppressed groups (74-85). Hence, the genre has a capacity of "speaking up for the speechless, giving a voice to the voiceless" (Cosslett 65).

This idea has some bearing combined with an ecocritical and animal studies approach, where nature and the non-human animal are the subordinated and silenced Others, as pointed out by Manes (15) and Donovan (210). The communicative skills of the horse and the humans surrounding him are at stake here. Going against a Cartesian conception of the animal as a machine, and the behaviorist theories following that thought, an animal studies approach in combination with posthumanism offers new insights, problematizing the ability of the horse to respond to human speech, and the lack of interest humans take in trying to understand non-human animals, as noted by Donna Haraway (When Species Meet 16-17) and Donovan (209). In literary representations, the body movements of the horse as well as 
his use of the gaze become central to the characters interpreting him (for similar discussions on the animal gaze, see Derrida 372; Haraway, When Species Meet 20-23; McFarland 157). One way of doing this is to describe the horse's behavior as understandable by making it more human, by anthropomorphizing, defined by Greg Garrard as the strategy of assigning human traits to animals (154). Othering is another technique available to the author, when offering an interpretation of the horse's behavior based on the idea that the horse is fundamentally different from humans. One particular way of achieving this while at the same time giving a positive image of the horse is through allomorphism, which Garrard defines as a way of Othering while assigning value to the animal, depicting the animal as Other and superior to humans (154). From a posthuman perspective, the question of "likeness and difference" is a way of simultaneously, ironically bringing forth and questioning "boundaries between the human and the non-human, to facilitate a dialogue as to how those very borders might become more fluid" (Jaques 2-3). Along the same lines, Amy Ratelle suggests:

It is possible $[\ldots]$ that the act of anthropomorphizing an animal is not necessarily rooted in what we, as humans, wish to ascribe onto the animal to suit our own cultural or symbolic requirements, but instead express something we receive from the animal, when we are situated together in mutual understanding. (Ratelle 1)

To understand the horse, as Donovan argues, also requires a certain attitude of compassion and care (213), as you would find between companion species, according to Haraway (The Companion Species Manifesto 12). Using this lens is particularly fruitful in fiction about horses where the narrator is human, as in the series on Klara.

\section{The Talkative Vitnos as an Expression of the Silenced Child}

The first section of this article will illustrate how Vitnos shares certain aspects of the child narrator as different from an adult, supported by Maria Nikolajeva's claim that "[n]ormally it is assumed that animals [...] represent children, that is, are child characters in disguise" (157). The differentiating between adult and child (in this case Vitnos) consists of the latter displaying knowledge gaps, surprise and a steep learning curve, often associated with physical pain or humiliation. Furthermore, the nature of the adults' relation to children is similar to that of humans to animals. Society silences certain 
groups of people, such as "women, minorities, children, prisoners and the insane" (Manes 16). Neither children nor animals are part of society, and "the voices of animals and their advocates [were] silenced by the ideological formations of the modern era" (Donovan 213). In the case of the child character in children's books, as well as Vitnos, the society responsible for the silencing clearly belongs to the adult world, both human and animal. What Rudolfsson does when making Vitnos the narrator of the story is "speaking up for the speechless, giving a voice to the voiceless" (Cosslett 65), children and animals alike.

Consequently, the human-animal dichotomy is less rigid when it comes to children, often seen as closer to nature, occupying a position in between according to Zoe Jaques (9-10), or holding a dual position, as Aliona Yarova argues (2). Manes draws attention to what he terms "animistic reflexes": "Children talk to dolls and animals without being considered mentally ill, and are, in fact, read fairy tales, most of which involve talking animals" (18). This establishes a clear connection, a kinship of kinds, between animals and children, coming together in the stories of Vitnos as silenced subjects. The narrator Vitnos speaks directly to the reader in the text, presumably a child. The complicity created between horse and child through this narrative strategy places them in a similar category, apart from the adult world, which would typically silence both the horse and the child, following the logic of what Haraway calls human exceptionalism (When Species Meet 11), where human is limited to the rational, knowledgeable adult (man). Separated from the world of human adults, the child positioned as reader in the text gets to hear what the horse has to say, when finally finding the opportunity to speak and to be heard.

On multiple occasions, the foal narrator shares his knowledge with the child, the implied reader in the text, when the narrative introduces a phenomenon new to the horse, letting the reader discover it at the same time as the foal. In the first volume of the series, for instance, Vitnos meets a hedgehog, presented through the narrow lens of the ignorant foal:

Jag hade aldrig sett ett så märkvärdigt djur. Varför låg han så stilla? Ingen nos hade han. Och ingen svans heller. Och var hade han gjort av benen? [...] Jag sträckte förstås ner halsen så långt jag kunde och började nosa på honom. Och plötsligt rörde det konstiga djuret på sig! Hans päls reste sig rakt upp. Vassa taggar stack min nos. Jag gnäggade högt och hoppade åt sidan. 
(I had never seen such an odd animal. Why did he lay so still? He had no nose. And no tail either. And what had he done with his legs? [...] Of course, I stretched my neck as far as it would go and started to sniff him. And suddenly, the strange animal started moving! His fur stood straight up. Sharp pins prickled my muzzle. I made a loud neigh and jumped away.) (Rudolfsson, Vitnos 49-50) ${ }^{1}$

Vitnos' way of depicting the hedgehog underlines his naïve look at the world and the curiosity that guides his actions. Talking about its pins as fur, for example, unfolds the process of learning, but in a quite painful fashion. In the narrative, these occasions add to the dynamic and the suspense of the story, as a kind of "[p]icaresque adventure" (Cosslett 64). They also offer a possibility to identify with the foal narrator, or on the contrary, to feel superior to the horse, if one is familiar with the hedgehog. Nikolajeva claims that the child reader "can feel strong, clever and protective" (155) when comparing themselves to animals, because "[i]n the vast majority of stories, animals are used to empower the human child, the character as well as the reader, who feel superior to the beasts" (156). This could also be true for the stories of Vitnos. Regardless, Vitnos receives human attributes, through his use of human language when speaking to the reader in the text, and through his playful attitude in discovering the world, a curiosity one imagines that he shares with human children. The use of anthropomorphic traits engages the reader to consider Vitnos as a child.

At times, Vitnos encounters adult animals, which position him as either ignorant or as a child:

Och på trappan låg något som såg ut som en svart boll. Jag stack ner nosen och luktade på bollen. Då rörde den sig. Det var ju ett djur, såg jag. Djuret tittade på mig med gula ögon och gäspade.

- Vem är du? frågade jag. Du har en vit nos precis som jag. Och så har du en vit hov.

- [...] Jag är en katt. Och katter har tassar. Inte hovar, som dumma hästar.

(And on the doorstep, there was something that looked like a black ball. I stuck my nose down and smelled the ball. Then it moved. It was an animal, I discovered. The animal looked at me with its yellow eyes and yawned.

- Who are you? I asked. You have a white muzzle just like me. And you have a white hoof.

- [...] I am a cat. And cats have paws. Not hoofs, like stupid horses.) (Rudolfsson, Vitnos 85-86) 
While Vitnos compares the animal to himself, the cat clearly considers herself far superior to him and explains the difference while insulting him. There is a hierarchy among the animals in the stories about Vitnos, where the innocence of youth results in an inferior position. The use of the comparison between the cat and a ball, an object familiar to most children but less likely to be known by a foal, up until very recently living in the forest, underlines the humanness of the foal, the likeness with human children. Nikolajeva states: "When animals appear as literary characters they are ascribed human traits, both behavioral and intellectual. Even when animals are presented in their natural habitat, their emotions and thoughts are patterned according to human models" (155). In the case of Vitnos, one could argue that the childishness of the foal-narrator works exactly in this way. Through the use of human language and the supposed innocence of children discovering the world, thus anthropomorphizing the foal, the author creates a connection with the child reader in the text. Reading this another way, while still underlining the resemblances between foal and child, the similarity established would signal a possible disintegration of the separation between human and non-human animals, rather than upholding the animal character as a human in disguise. In fact, "[b]y drawing upon the ways in which non-human animals are like us, the human-animal boundary accordingly becomes much more permeable and an ethics of equality seems easier to obtain," Jaques explains (12). Hence, anthropomorphism may work in a slightly different manner, shaping the horse as something other than a human child or a "fur-covered human" (McFarland 154).

\section{Allomorphism as a Strategy for Portraying Horses as Superior to Humans}

In parallel to instances where Vitnos is presented as a child, he simultaneously comes across as someone who shares knowledge that he possesses, introducing it to the reader in the text who presumably hears this for the first time. In these instances, the human is often

pointed out as the less knowledgeable and the horse as the expert:

Du tror förstås inte att man kan stå och sova. Det kan man visst. Om man är en häst förstås. Vi kan knäppa på ett litet lås inne i våra knän. Och så kan vi stå och sova hur länge som helst, utan att ramla omkull. Det är ett riktigt bra sovsätt, när man inte vill ligga. Försök får du se! Men nej, oj, vad dum jag är. Du kan ju inte för du är ju ingen häst. 
(You don't think one can sleep standing up, do you? Of course you can. If you're a horse. We can lock a small hinge in our knees. And then we can sleep standing up for however long we want to without tipping. It is a really good way to sleep when you don't want to lie down. Try and you'll see! Oops, how stupid of me. You can't because you're not a horse.) (Rudolfsson, Guldvinge 12)

In this example, Vitnos clearly adopts a different perspective than above. His voice appears to be that of an older child, explaining the world to another, far less knowledgeable. More than this, Vitnos points out how he is different from his implied reader, who is human. This seems to be a case of allomorphism, a strategy of placing the animal above the human, giving it more value, "a kind of superiority" (Garrard 154). Garrard defines allomorphism as "representation of animals as radically different from humans, but with no derogatory implications" (206). At this point, the obvious risk in considering Vitnos a child appears, when he establishes a clear-cut line between his implied reader and himself.

In other instances, Vitnos acts more like a guide, explaining the benefits of a morning stroll in the forest to the child reader in the text:

Du skulle faktiskt pröva på att stiga upp tidigt en sommarmorgon och gå på en promenad i skogen. Du förstår, det doftar så JÄTTEHÄRLIGT där då. Innan träden och gräset och mossan och barren blivit varma av solen. Och innan djuren ens druckit upp all daggen.

(You really ought to try getting up early in the morning on a summer day and go for a walk in the woods. You see, it smells SUPER WONDERFUL there at that time of the day. Before the trees and the grass and the moss and the pine needles have been warmed up by the sun. And even before the animals have drunk all the dew.) (Rudolfsson, Kattungen 6, capitals in the original)

The next page is devoted to an explanation of what dew is. Vitnos tries to hide his lack of knowledge, or rather promotes his friend Vips, a slightly older foal, on whose knowledge he relies to answer a question supposedly asked by the reader. The repetition of the question by Vitnos - "Vad dagg är?" ("What dew is?") - underlines the dialogical aspect of the story told, and the narrative voice of Vitnos mimics that of an older child or an adult telling the story to the child reader. Vitnos' appeal to the senses in his description serves as an invitation to reconnect with nature through smell and taste, reminding the reader of what capacities of enjoyment horses and humans share. In this and other instances, the stories of Vitnos function as tales of 
nature, according to Cosslett designed to teach the reader something about nature and the animals living there (64).

Besides telling the child reader in the text of his lack of knowledge compared to the horse, and giving advice about connecting with nature, Vitnos takes every opportunity to talk about how little human adults understand of how the horse functions. For example, Vitnos comments on the fact that he has to spend the winter nights indoors:

För att inte frysa, säger husse. Fast han vet ju inte vad han pratar om. Egentligen kan vi russ gå ute hela året om. Det gjorde vi när vi var små och bodde bland de andra vilda russen på Gotland. Då växte vår päls så att den blev jättetjock och lurvig, och då frös vi nästan aldrig. Hemma i Lojsta-skogen fanns också mycket vi kunde äta på vintern. Äter man mycket så håller man sig frisk och varm. Det lärde mig min mamma.

(In order not to be cold, master says. But he doesn't know what he is talking about. In fact, we ponies from Gotland can spend all year round outside. That's what we did when we were little and lived among the other wild ponies of Gotland. Then our fur would grow really thick and shaggy, and we were hardly ever cold. At home, in the woods of Lojsta, there was a lot to eat in the winter too. If you eat a lot, you stay healthy and warm. That's something my mom taught me.) (Rudolfsson, Guldvinge 5-6)

The explanation that Vitnos offers the implied child reader draws on generational knowledge, passed down from mother to foal, clearly indicating a proximity to the natural world that the horse invites the child in the text to recognize. Humans, excluded from this chain, interpret the weather conditions from their perspective and treat the pony as they would like to be treated, thus submitting the horse to an anthropocentric world view, against which Vitnos protests. Reading this against the backdrop of the thoughts of Donovan, this comes across as subversion of the hegemonic adult human voice. While presenting the results of an interview study performed with young girls, Donovan establishes a link between the oppressed female voices and that of animals. According to her, "when oppressed and dominated groups' views are heard, their views are found inevitably to be subversive of the ideological system that would render them silent - sexism in the case of women and girls; speciesism in the case of animals" (210). Donovan defines speciesism as "the belief that humans are superior to animals and therefore have the right to use them for their own purposes" (211). Speaking with Johnson, speciesism is 
"the systematic neglect of nonhuman interests," "a form of discrimination that is fundamentally similar to racism (or sexism), where the interests of the members of one race (or sex) count more than the like or greater interests of members of another" (11). Although, Vitnos' master acts out of concern, his interaction with the horse generally unveils a wish to control and have the pony silently accept his command, often giving Vitnos the occasion to "satirize human behavior" (Cosslett 64), because he finds ways to disobey his master without punishment. Vitnos is clearly a subversive power against adult authority, and through sharing secrets with Vitnos the child reader in the text has been what Nikolajeva calls an accomplice in the subversion (162). In the end, since only the child reader in the text listens to the foal, the resistance put up by Vitnos would seem useless, unless the child would tell the adults, which is perhaps what the author had in mind, raising a cautious finger against authoritarian methods for training horses as well as stable cultures for originally wild ponies. In Cosslett's words, Vitnos would mask the author's voice, sending a clear message to take the side of the pony (63-64).

Vitnos continues to stress the failure of humans when speaking of language. For instance, he points out the following:

$[H]$ ästar förstår människospråk mycket bra. Lika bra som alla andra djur. Det är bara människor som inte begriper när djur talar med varandra.

([H]orses understand human language very well. Just as well as all other animals. Only humans fail to understand when animals talk to one another.) (Rudolfsson, Vitnos 74)

This puts the child reader in the text in a privileged position since the narrative is addressed to them directly and understandable to them, in perfect concordance with Cosslett's statement that "the animals cannot be understood by most humans, except the readers. The child, 'nearer' to the animal, can understand them" (74). True or not, Vitnos' declaration divides humans from other animals, giving them less knowledge and possibly explaining certain problems in interspecies interaction, once again an example of allomorphism as defined by Garrard (206), giving higher value to the horse. In these instances, it is also through the narrative voice of Vitnos that the process of Othering takes place. Vitnos describes the differences between horses and humans on numerous occasions, putting the humans in the position of the Other, as what is opposite yet inferior to the horse. 
The question of animals and language preoccupies philosophers and animal studies scholars alike. For instance, it is at the center of Jacques Derrida's thoughts, as he criticizes the philosophers he studies:

All the philosophers we will investigate (from Aristotle to Lacan, and including Descartes, Kant, Heidegger, and Lévinas), all of them say the same thing: the animal is without language. Or more precisely unable to respond, to respond with a response that could be precisely and rigorously distinguished from a reaction, the animal is without the right and power to "respond" and hence without many other things that would be the property of man. (Derrida 400)

This position, held by the philosophers in Derrida's discussion, stands in stark contrast to what occurs in the tales of Vitnos, where the capacity of animals not only to understand but also to make themselves understood by other species is normalized, in opposition to the common idea that the ability to communicate through language is reserved for humankind. To be precise, it is a matter of being able to respond as opposed to react. Linking these thoughts to animal studies can prove useful. Donovan cites several theorists whose position on the question of human versus animal languages is that "it is not a matter of whether animals have language; it is rather that humans have not as of yet learned those languages or paid sufficient attention to be able to decipher them" (212). The stories told by Vitnos seem to agree with this statement, calling into question the anthropocentrism at the heart of the opposing view.

\section{Klara as the Voiceover and Interpreter of the Silent Horse}

These examples discussed above have been taken from narratives where the horse's voice can be heard directly, but what can we observe when the horse is not the narrator of the story and, consequently, stays silent? As previously pointed out, the non-human world consists of silenced subjects, in comparison with the humans, who dominate the discourse (Manes 15-16), and just as women are oppressed by patriarchal structures that silence them, so animals are dominated and silenced by society (Donovan 210-213). This perspective is the prevailing one in fiction about horses, in the sense that the horse seldom gets to speak for himself. Contrary to what we have seen thus far in the books about Vitnos, where the horse constructs the human as Other, Hagmar has chosen the human perspective as the dominating one, using Klara as narrator and as the main focalizer. Hagmar's way of depicting the horse relies both on processes of 
Othering and anthropomorphizing, making the horse more human, or understandable only through the lens of humanity.

In volume six of the series about Klara, Klaras ridlägersommar, where she spends part of her summer holidays at a nearby equestrian center with her pony in order to acquire new skills, the opening scene of the book describes the horse from the point of view of humans:

Mutor hjälper inte. Övertalning är lönlöst. Hotelser, böner och gråt ger ingen effekt alls. Det spelar ingen roll vad mamma och jag gör, Star vägrar ändå att gå in i transporten. Han frustar upprört och kastar med huvudet så hans långa man flyger. Envist spjärnar han emot och de blankpolerade hovarna är som fastspikade i marken.

(Bribes will not do. Persuasion is fruitless. Threats, pleas and tears have no effect at all. It doesn't matter what mom and I do, Star still refuses to enter the trailer. He snorts indignantly and throws his head, his long mane flying around his head. Stubbornly he resists, his shining hoofs nailed to the ground.) (Hagmar 5)

Two words show the human point of view here: indignantly and stubbornly. The narrator invites the reader to adopt the same view of the situation, thus normalizing this particular interpretation of the pony's behavior. Klara is the main focalizer, and she tries to comfort the pony, inferring that fear is the reason behind his resistance. However, Klara's mother, a very experienced rider, protests with disdain, saying that Klara should look at him, he is just being unusually willful and stubborn. After a physical portrait of the pony, Klara's thoughts are as follows when she sees his eyes:

Mamma har rätt. Det finns ingen rädsla i hans blick, bara tjurighet kryddad med en nypa bus. Han vet mycket väl att det inte är farligt att gå in i transporten. Men han har helt enkelt inte lust och det verkar som han tycker att det är roligt att reta oss.

(Mom is right. There is no fear in his eyes, just stubbornness spiced with a bit of mischief. He knows very well that it isn't dangerous to enter the trailer. But he simply doesn't feel like it and it seems as if it amuses him to tease us.) (Hagmar 6)

The perspective offered is filtered through both Klara's and her mother's eyes and thus highly normalized as well as anthropomorphic. By interpreting the horse's behavior according to human standards, Klara speaks for the horse, making her anthropocentric perspective 
the prevalent one. Her first instinct is to consider the horse as Other - as a horse he is afraid of unknown, confined spaces - but, led by her mother to believe that the horse is playing with them, being stubborn, ends up humanizing the horse in order to understand him more readily. Anthropomorphism has, in fact, both a positive and negative side: "while it might seem that anthropomorphism engenders kindness towards animals and acceptance of their agency, in its crude form it is really a way of not seeing animals in their own right at all" (Garrard 165). It is, of course, positive to acknowledge the feelings or the agency of the animal and more negative to simplify by explaining a behavior in human terms to make it easier to comprehend, as may be the case here, or not to see the animal as animal.

According to Derrida, "[e]ven those who, from Descartes to Lacan, have conceded to the said animal some aptitude for signs and for communication have always denied it the power to respond - to pretend, to lie, to cover its tracks or erase its own traces" (401). This passage about Klara's pony contradicts these philosophers, showing the horse pretending to be scared when in fact he is playing a prank. How should one interpret this depiction of the horse, then? Either as a case of anthropomorphism, making the horse's ways comprehensible only via a comparison with human behavior, or an example of a human misreading the horse - he may be just scared - or as an attempt to assign humor to the horse? The conclusion of the scene, where the pony jumps on the trailer in order to avoid having two ropes crossed behind to push him, and calmly starts eating the treats found inside seems to indicate that he was never really scared, thus normalizing the interpretation provided by the narrative.

Later on in the same book, Klara is out alone in the forest with her pony Star, when he starts to behave in a way that is incomprehensible to Klara. He stops all of sudden, refuses to walk on, his body all tensed. When Klara tries to get him to turn around and go home, he resists. He repeats this several times until she starts to listen and tries to find out what he has discovered. It turns out to be another girl from Klara's group, who has had an accident. Unable to move, she is trapped under her horse, whose front legs are all tangled up in the reins. Klara manages to help the girl, and Star finds his way back through the woods (Hagmar 127-149). In this example, the main interpretation Klara has of the horse's behavior is that he is annoying when she can't get him to move (128), stupid when she can't get him to stop (129), but when she understands what is at stake, she praises him and gives him a cuddle (138). The Othering of Star serves the purpose of distinguishing between the knowledge of the horse, 
silent and in appearance vague, and that of the human, who is insensitive at first but later accepting. It also shows the inadequacy of the human senses in comparison with those of the horse. In addition, it reveals why the human needs to trust the horse, giving the horse time to get his point across without access to human language, which boils down to "recognizing and valuing heterogeneous beings outside of debilitating hierarchies" (Jaques 13).

Sarah E. McFarland shows a similar moment in her analysis of the interaction between the human and the tiger in Yann Martel's Life of $P i$ (2001), resulting in a mutual silent accord where the tiger accepts the presence of the boy and lets him live (McFarland 157). Although the difference between a tiger and a horse is simply explained as the divide between hunter and prey, the implication may be similar for the human part. A horse is a big and strong animal. Not listening to its signals may involve real danger. On the other hand, paying attention to the silent but persistent horse does pay off in the case of Klara and Star, just as it does for Pi in Life of Pi. The subtle didactic dimension consistent with books for children and young adults shines through.

Neither the books on Vitnos nor those on Klara display an acceptance of the Cartesian behaviorist claim of stimulus and response the horses in interaction with people are even depicted going against their primary instinct because they listen to the person they trust. In addition, the people around the fictional horses, portrayed as caring and attentive to the animals, open up for true interspecies communication. As Donovan claims: "Eminent authorities on animal behavior [...] have provided reams of evidence supporting the claim that animals are conscious subjects who really communicate their wishes, should humans take the trouble to hear them" (208-209). The examples provided above demonstrate how "the modes advocated in care theory - sympathy, empathy, and attentiveness - are the ways in which animals' communications can be read, their languages learned, and their wishes understood" (Donovan 213). Furthermore, Donovan explains:

Care theory thus focuses on the particular individual and on personal encounter, requiring a personal knowledge of that individual's history, when possible, and his characteristic behavior, known through repeated experiences with that individual. Such knowledge comes [...] from attentive observation. (Donovan 214-215)

In order for there to be knowledge, concludes Donovan with support from Barbara Smuts, there needs to be "encounters between subjects" 
(Donovan 219). This is exactly what happens between Klara and her pony Star. As soon as she considers him a subject with a message to convey, she starts listening and acts according to his wishes.

\section{Concluding Remarks}

To sum up the findings of the analysis, there is an anthropomorphic use of Vitnos as the narrator of the story, expressing himself using human language, in certain instances comparable to the voice of a child with limited knowledge of the world. Other examples, however, show how the horse narrator points out the division between horse and human, the horse generally depicted as the smarter of the two, using allomorphism placing the horse above the human. The horse narrator ascribes value to his own species but also to all inhabitants of the forest. As seen through the eyes of the horse, the natural world becomes understandable to the reader, but also more human. The humans in the stories about Vitnos understand very little about the horse and other animals, and the foal narrator functions as a kind of guide, inviting the reader to look differently and with more respect and compassion at the horse and his fellow creatures. He teaches the reader to "listen [...] to the nonhuman world (i.e., treating it as a silenced subject)" (Manes 16). Giving voice to the horse allows us to listen to the silenced subject, but it also creates a certain image of the horse, perhaps distorted. One could wonder whether the allomorphic features found in the narratives serve to establish and perpetuate the separation between human and non-human animals or if the stories contribute to building within the reader a greater sympathy for non-human animals and the natural world.

Where the books about Klara are concerned, the narrative choices made create a different image of the horse, relying on the interpretation of the human, using anthropomorphism in order to explain what the body of the horse seems to convey, but regularly showing the superiority of the horse using allomorphism and at the same time more subtle strategies of Othering. Perhaps one could say that regardless of whether the horse is the narrator or depicted through the human characters of the story, there seems to be a tension between Othering and anthropomorphism. Vitnos may construct the human as an inferior Other in his own words, but Star does the same in his subtle way. Both series of books present us with an image of the horse as the more competent in all kinds of situations. Hagmar and Rudolfsson both give human traits to the horse, offering a human perspective in order to understand the non-human animal, and both depict horse and human as each other's Other. 
Biograhpical information: Ann-Sofie Persson is an Associate Professor in Language and Culture, specialized in French and Comparative Literatures, at the University of Linköping. Her research interests include ecocritical perspectives on horse stories in literature for children and young adult readers as well as postcolonial francophone autobiographical narratives from the Caribbean and North Africa with a particular focus on gender issues.

\section{Works Cited}

Asklund, Helen. "Hästflickan i förändring i Linn Hallbergs och Pia Hagmars hästböcker" [The Horse Girl in Transformation in Linn Hallberg's and Pia Hagmar's Horse Books]. Flicktion: Perspektiv på flickan i fiktionen [Flicktion: Perspectives on the Girl in Fiction], edited by Eva Söderberg, Mia Österlund, and Bodil Forsmark, Malmö, Universus Academic Press, 2013, pp. 243-257.

Cosslett, Tess. Talking Animals in British Children's Fiction, 1786-1914. Aldershot, Ashgate, 2006.

Derrida, Jacques. "The Animal That Therefore I Am (More to Follow)." Translated by David Wills, Critical Inquiry, vol. 28, no. 2 Winter, 2002, pp. 369-418, www.jstor.com/stable/1344276. Accessed 10 August 2020.

Donovan, Josephine. “Interspecies Dialogue and Animal Ethics: The Feminist Care Perspective." The Oxford Handbook of Animal Studies, edited by Linda Kalof, New York, Oxford University Press, 2017, pp. 208-224.

Garrard, Greg. Ecocriticism. London/New York, Routledge, 2012.

Hagmar, Pia. Klaras ridlägersommar [Klara's Riding Camp Summer]. Stockholm, Wahlströms, 2000.

Haraway, Donna. The Companion Species Manifesto: Dogs, People, and Significant Otherness. Chicago, Prickly Paradigm Press, 2003.

---. When Species Meet. Minneapolis, University of Minnesota Press, 2008 .

Hedenborg, Susanna. "Från Svarta hingsten till Klara, färdiga, gå..." [From The Black Stallion to Klara, färdiga, gå...]. Hästkarlar, hästtjejer, hästälskare: 100 år med Svenska ridsportförbundet [Horse Men, Horse Girls, Horse Lovers: 100 Years with the Swedish Equestrian Federation]. Strömsholm, Svenska ridsportförbundet, 2013, pp. 175-191. 
Jaques, Zoe. Children's Literature and the Posthuman: Animal, Environment, Cyborg. New York/London, Routledge, 2015.

Johnson, Kathleen R. Understanding Children's Animal Stories. Lewiston/Queenston/Lampeter, E. Mellen Press, 2000.

Manes, Christopher. "Nature and Silence." The Ecocriticism Reader: Landmarks in Literary Ecology, edited by Cheryll Glotfelty and Harold Fromm, Athens/London, The University of Georgia Press, 1996, pp. 15-29.

McFarland, Sarah E. "Animal Studies, Literary Animals, and Yann Martel's Life of Pi." The Cambridge Companion to Literature and the Environment, edited by Louise Westling, New York, Cambridge University Press, 2014, pp. 152-165.

Nikolajeva, Maria. Power, Voice and Subjectivity in Literature for Young Readers. New York/London, Routledge, 2010.

Nyrnes, Aslaug. "Jente-hest-kameratskap på tvers av artar: Hesteboka i økokritisk perspektiv" [Girl and Horse as Companion Species: Horse Fiction in an Ecocritical Perspective]. Barnelitterært forskningstidsskrift, vol. 10, 2019, pp. 1-9, doi.org/10.18261/issn.2000-74932019-01-11.

Ratelle, Amy. Animality and Children's Literature and Film. London, Palgrave Macmillan, 2015.

Rudolfsson, Marie Louise. Vitnos, det lilla russet [Vitnos, the Little Russ]. Stockholm, Wahlströms, 1971.

---. Vitnos räddar Guldvinge [Vitnos Saves Guldvinge]. Stockholm, Wahlströms, 1975.

---. Vitnos och den bråkiga kattungen [Vitnos and the Mischievous Kitten]. Stockholm, Wahlströms, 1976.

Yarova, Aliona. "'You Are a Mysterious Animal, You Know': EcoPhilosophy in Sonya Hartnett's The Midnight Zoo." Barnboken: Journal of Children's Literature Research, vol. 39, 2016, doi.org/10.14811/clr. v39i0.239.

\section{Notes}

1 All translations of Rudolfsson and Hagmar are mine. 